\title{
The Foreign Vocabulary of the Glorious Qur'an
}

\author{
Rose Aljanada \\ Department of Languages and Translation \\ Arar Community College \\ Northern Border University \\ Kingdom of Saudi Arabia \\ AseelAlfaisal \\ Department of Languages and Translation \\ Arar Community College \\ Northern Border University \\ Kingdom of Saudi Arabia
}

\begin{abstract}
When talking about foreign vocabulary of the Glorious Qur'an, different arguments took place and affected the line of researche on Qura'nic studies. Some scholars were against the idea that the Glorious Qur'an has foreign words. Other scholarsargued against that, claiming that the existence of foreign words in the Glorious Qur'an would reflect the richness of Arabic and the excellence of the Qur'an. In the middle of these two points of view, lies the convincing argument that both points of view are not wrong: those who claim that there are foreign words in the Glorious Qur'an are right because the origins of these words are Persian, Syriac, Ethiopic, or Hebrew etc. and those who reject this claim are also right because these words were adopted into Arabic and were Arabicized so they became integrated in the Arabic language.
\end{abstract}

Keywords: Language, Qur'an, Arabic, vocabulary in the Qur'an, Qur'anic language , foreign vocabulary, Arabicization.

When talking about foreign vocabulary of the Glorious Qur'an, different arguments took place and affected the line of researche on Qura'nic studies. Some scholars such as ImamAl-Shafi'i and Ibn-Jarir were against the idea that the Glorious Qur'an has some foreign words. (As- Suyūṭi \& Abū-Sikkīn, 1980, p.57). Their proof is basically the Aya [verse]:

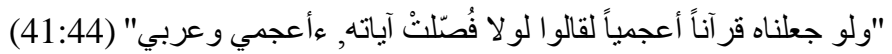

[And if We had sent this as a Qur'an in a foreign language (other than Arabic), they would have said: "Why are not its verses explained in detail (in our language)? What! (A Book) not in Arabic and ( the messenger) an Arab?"] and some other Ayas [verses] such as “قر آناً عربياً (12:2) [Arabic Qur'an] (12:2) and "عربيٌ مُبين (this (the Qur'an) is a clear Arabic tongue] (11:2), (The Noble Qura'n (41:44), King Fahd Complex for the Printing of the Holy Qur'an, 2006) .

On the other hand, As-Suyuti and Ibn-Abbas(1980) argued against that, claiming that the existence of foreign words in the Glorious Qur'an would reflect the richness of Arabic and the excellence of the Qur'an to inform people of the new and best items such as Istabraq ستبرق[brocade], and misk [سك [musk], (p.58). So it does not limit people's knowledge by the simple civilization of the Arabs of the Jahiliyya [pre-Islamic paganism]. In the middle of these two points of view, lies one convincing argument.

Abu Obaid and As- Suyūṭī (1980) states that both parties to the arguments are not wrong: those who claim that there are foreign words in the Glorious Qur'an are right because the origins of these words are Persian, Syriac, Ethiopic, or Hebrew etc. and those who reject this claim are also right because these words were adopted into Arabic and were Arabicized so they became integrated in the Arabic language, (p. 62-65). As- Suyūṭ̂̄ (1980) points out that:

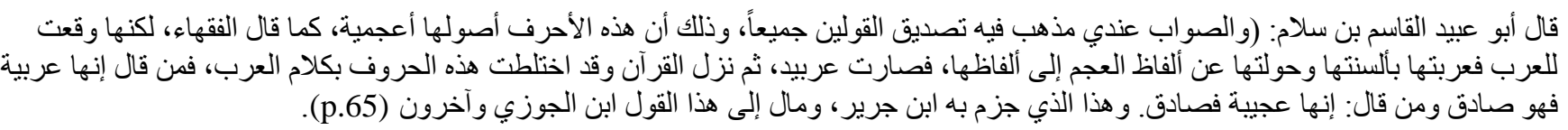
Although the claim that no foreign words are there in the Qur'an seems fairly persuasive to the researchers, one should not deny the fact that there are in the Qur'an some foreign words but which cannot raise a doubt about the Qur'an being

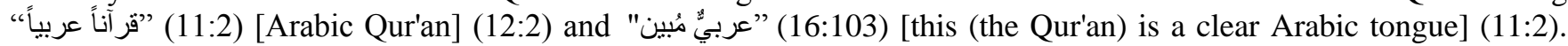


Foreign words from other languages would reflect the historical and linguistic environment at that time. Arabic, Syriac, Hebrew and Aramaic are all Semitic languages and all had the same origin which entails that these languages have a number of words and expressions in common, though their connotations have been changed by time and locality.Turning back to Aya [verse]: "عربيٌ مُبين" (16:103) [this (the Qur'an) is a clear Arabic tongue] (16:103), the Glorious Qur'an is still considered pure Arabic in spite of the fact that Arabic borrows, as all languages do, from previous dialects and languages. It is pure Arabic as a whole. The Qur'an is clear in its source, its laws and its commands. The fact that some of the words of the Qur'an are of a foreign-origin does not refute the purity of the Qur'anic Arabic, these words had already been adopted by the Arabs in their speech and literature. What was specific about the Arabs at the time of revelation was that they came into contact with other cultures due to trade and then had borrowed certain words. According to Al-Shafi'i, these foreign words in the Qur'an had been fully integrated into Arabic and were already a part of the language. They had already been naturalized into the Arabic language before the revelation of the Qur'an and they were already in use, (As- Suyūṭī\&Abū-Sikkīn, 1980, p.57).

To illustrate this point of view, the followings are some foreign words derived from different languages such as Ethiopic, Persian, Greek, Hebrew, Syriac, Coptic, Indian, and other languages, (Jeffery ,2007, p. 12-28). Notice that the numbers indicated between brackets are verses and chapters where every word is mentioned, followed by the English translation as provided in Cowan's 1980 Dictionary of Modern Written Arabic or in the 2006 English translation of the Noble Qura'n of King Fahd Complex for the Printing of the Holy Qur'an.

\section{- Persian:}

○ Barzakhخر برز interval (23:102; 55:20; 25:55), (Cowan, 1980, p.52).

○ Firdous فردوس Paradise (18:107; 23:11), (Cowan, 1980, p. 704).

○ Zanjabil زنجبي ginger (76:17), (Cowan, 1980, p. 383).

o Sijjil سجيل baked clay (105:4), The Noble Qura'n (105:4), King Fahd Complex for the Printing of the Holy Qur'an, 2006) .

○ Khandaq خند trench [not mentioned the Nobel Qur'an but in the story of the Battle of the Trench], (Cowan, 1980, p. 263).

\section{- Syriac:}

○ Dawud داوود David (4:163; 5:78; 6:84), (List of people in both the Bible and the Quran, n.d.)

- Sulayman سليمان Solomon (2:102; 4:163; 6:84), (List of people in both the Bible and the Quran, n.d.)

- Isa عيسى Jesus (2:87; 2:136; 2:235), (List of people in both the Bible and the Quran, n.d.)

○ Nuhz Noah (3:33; 3:44; 4:163),(List of people in both the Bible and the Quran, n.d.)

\section{- Hebrew:}

Jahannamis hell (2:206; 3:12; 3:162), (Cowan, 1980, p. 144).

جبريلGabriel (2:97; 2:98; 66:4), (Cowan, 1980, p. 111).

Shaytan شيطان Satan (2:36; 2:168; 2:208), (Cowan, 1980, p. 497).

Sadaqahة صدقة charity $(2: 196 ; 2: 263 ; 4: 114)$, (Cowan, 1980, p. 509).

Surah سورة chapter (2:23; 9:64; 10:38), (Cowan, 1980, p. 441).

Ma'idahoائد "a dining" table ( 5:112; 5:114), (Cowan, 1980, p. 933).

Sakinah سكينة tranquility (2:248; 48:4; 48:18), (Cowan, 1980, p. 418).

Taharaةa purity, (Cowan, 1980, p. 570), (not mentioned in the Nobel Qur'an but inHadeeths books like Sahih AlBukhari and Sahih Muslim as in this Hadeeth in Sahih Muslim, Book 3, Hadeeth 2:

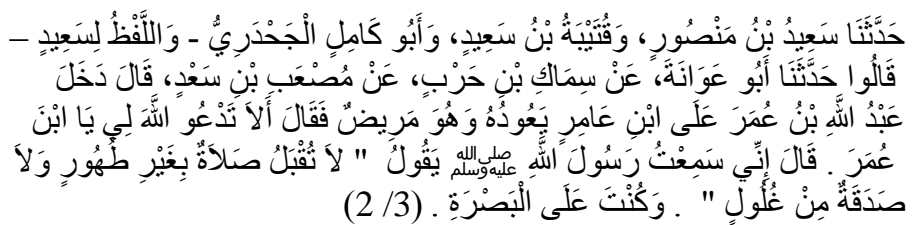

Mus'ab b. Sa'd reported: 'Abdullah son of Umar

came to Ibn'Amir in order to inquire after his health

as he was ailing. He said Ibn'Umar, why don't you

prayto Allah for me? He said: I heard of Allah's

Messenger (may peace be upon him) say: Neither

the prayer is accepted without parification nor is

charity accepted out of the ill-gotten (wealth), and

thou were the (governor) of Basra. (Sahih Muslim,

Translated by: Abd-al-Hamid Siddiqui, 2000 ). 
○ Kanisah صومعة / كنيش Church, Kinnesset, monk's cell, hermitage (22:40), (mentioned in the Nobel Qur'an in the plural form صوامع), (Cowan, 1980, p. 525).

- Christian Abyssinian (Ethiopic):

○ Mirhab محر a prayer niche (3:37; 3:39; 19: 11), (Cowan, 1980, p. 166).

- Minbar منبر pulpit, (Cowan, 1980, p. 939). (not mentioned in the Nobel Qur'an but inHadeeths books like Sahih AlBukhari and Sahih Muslim as in this Hadeeth in Sahih Muslim, Book 54, Hadeeth 1861:

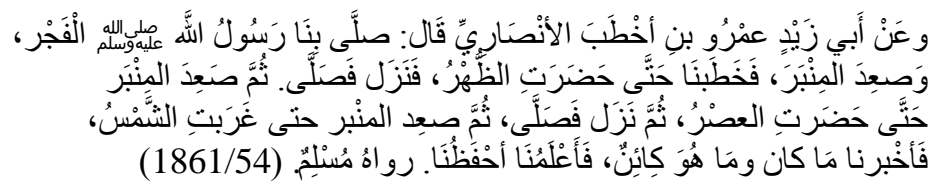

Abu Zaid (viz. Amr b. Akhtab) reported: Allah's

Messenger (may peace be upon him) led us in the

dawn prayer and then mounted the pulpit and

addressed us until it was (time for the) noon prayer.

He then came down the pulpit and observed prayer

and then again mounted the pulpit and again

addressed us until it was time for the Asr prayer. He

then again came down and observed the prayer and

again mounted the pulpit and addressed us until the

sun was set and he informed (about) everything

(pertaining to turmoil) that lay hidden in the past and

what lies in (the womb) of) the future and the most

learned amongst us is one who remembers them well.

Siddiqui, 2000 ).

(Sahih Muslim,Translated by: Abd-al-Hamid

○ Burhan برهانp proof (2:111; 4:174; 12:24), (Cowan, 1980, p. 418).

○ Hawariyoun الحواريون Jesus' disciples ( 3:52; 5:112; 61:14), (Cowan, 1980, p. 212).

- Greek:

○ Kharaj الخراج Land Tax, wage. Recompense (23:72), (Cowan, 1980, p. 233).

○ Dinar دينار dinar (monetary unit) (3:75), (Cowan, 1980, p. 306).

The foreign elements of this vocabulary are three kinds (Jeffery, 2007, p. 10). Firstly, words which are entirely nonArabic (such as zanjabi:1 زنجبيل [Ginger], Firdous فردوس [Paradise], Istabraqaتصنبرق [brocade] etc.) have no Arabic roots because their sources are foreign. Secondly, Semitic words whose trilateral roots are found in Arabic but are used in the Glorious Qur'an in another language's sense such as fater فاطر which means the creator in the Qur'an while its root /fatara/ means to break in Arabic. Thirdly, other words are commonly used in the Arabic language but the Qur'an has used them semantically in another language's sense. For instance, the word nu:r $r$, meaning light, is a common Arabic word but is used in the Qur'an to mean religion under the influence of the Syriac language use as in the Aya (verse):

"يُريدون أن يُطفئو ا نور الله بأفو اههم, ويأبى الله إلا أن يتم نوره ولو كره الكافرون" (9:32)

[They (the disbelievers) want to extinguish Allah's Light (with which Muhammad PBUH has been sent - Islamic Monotheism) with their mouths, but Allah will not allow except that His Light should be perfected even though the Kafirun (disbelievers) hate (it).] (The Noble Qura'n (9:32), King Fahd Complex for the Printing of the Holy Qur'an, 2006) .

Moreover, the presence of some foreign vocabulary which describes articles of luxury, precious items, and generally speaking, civilization shows the limitless images of the Qur'anic discourse. For instance, the words sundus سندسن

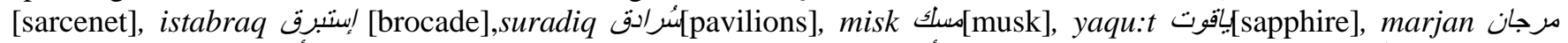

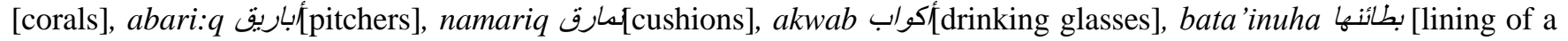
cushion], and zanjabi:l زنجبيل [Ginger] all indicate luxury and civilized life which should not be available at that time when Arabs generally led a hard life in deserts where they naturally do not have words belonging to the higher stages of civilization to which the Glorious Qur'an refers (Jeffery, 2007, p. 11).

As a conclusion, the foreign vocabulary which has become Arabicized even in pre-Islamic era suggests that there should have been changes in the language (Stetkevych, 1970, p. 95). 
Thus, these foreign words had already been integrated into the Arabic language and were accepted as part of pure literary Arabic. In general, words of foreign origins, when adopted by the literate of a language, become part of that language.

Table 1: Foreign vocabulary of the Glorious Qur'an

\begin{tabular}{|c|c|}
\hline Letter I & 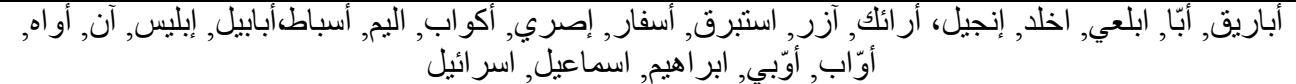 \\
\hline Letter ب & بطائنها ،بعير, برزخ، بيع, بر هان \\
\hline Letter ت & تتبير اً, تابوت، من تحتها، تنور \\
\hline Letter ج & جبريل, الجبت، جهنم, جناح \\
\hline Letter $ح$ & حصب, حطة, حوبأ، حواريون, حرام \\
\hline Letter $\dot{C}$ & 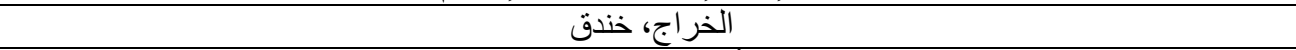 \\
\hline Letter د & درستُ, دينار، دُرِيّ, داوود \\
\hline Letter $\lrcorner$ & راعنا, ربانيون, ربيون, الرس, رمزاً, رهو أ, الروم, الرقيم \\
\hline Letter $j$ & زنجبيل \\
\hline س Letter & 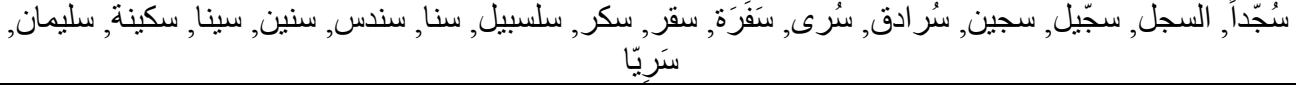 \\
\hline Letter ش & شطر, شيطان \\
\hline ص ص Letter & الصر اطر صُرْهن، صدقة \\
\hline Letter b & طه, طاغوت, طفقا, طوبى, طور, طوى, طهارة \\
\hline Letter $\varepsilon$ & عبّدْتَ, عدن, عمر ان, عيسى \\
\hline Letter $\dot{\varepsilon}$ & غساق, غيض \\
\hline ف ف Letter & الفردوس, فوم \\
\hline ق & قر اطيس, قسط, قسطاس, قس, قطنا, قفل, قمل, قنطار ق قسورة \\
\hline Letter S & كافور, كفر, كفلين, كوّرتْ, كنز \\
\hline Letter J & لينة \\
\hline Letter $?$ & مُنكأ, مجوس, مرجان, مرقوم, مزجاة, مسك, مشراب, مقاليد, ملكوت, مناص, منُسأته, منفطر, المهل, مائدة, \\
\hline Letter ن & ناشئة، نوح، نمارق \\
\hline Letter $\rightarrow$ & هُدْنا, هوْنا, هبت للك \\
\hline Letter $g$ & وزر, ور اءهم (أمامهم), وردة \\
\hline Letter ي & ياقوت, يحور, يس, يصهر, يم, اليهود \\
\hline
\end{tabular}

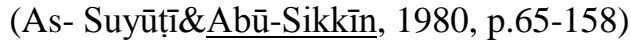

\section{References}

As- Suyūṭī G. \& Abū-Sikkīn, I. (1980). Al-Muhadhdhabfì-mā Waqa'afī Al-Qur’ānmin Al-Mu'arrab. Cairo, Egypt: Mațba'at al-Amāna .

As- Suyūṭ̂̄ G. (1991). Al-Muhadhdhabfì-māWaqa'afī Al-Qur'ān min Al- Mu'arrab. Retrieved from http://shamela.ws/browse.php/book-26097\#page-1

Cowan, J. (1980). A dictionary of modern written Arabic. ( $3^{\text {rd }}$ ed). Beirut, Lebanon: Librairie du Liban.

Al-Hilali, M. \& Khan, M. (2006). English Translation of the meanings and commentary of the Noble Qura'n.

King Fahd Complex for the Printing of the Holy Qur'an. Madinah, KSA: King Fahd Complex for the Printing of the Holy Qur'an. Print.

Jeffery, A. ( 2007).The foreign vocabulary of the Qur'ān. The Netherlands: Koninlijke Brill NV.

Siddiqui,A. (2000). Sahih Muslim. Retrieved from http://alislamic.net/hadith/muslim

Stetkevych, J. (1970). The Modern Arabic literary language: lexical and stylistic developments. London, England: Chicago University Press.

Wikipedia contributors. (2019, February 23). List of people in both the Bible and the Quran, The Free Encyclopedia.

Retrieved 19:56, February 28, 2019, from

https://en.wikipedia.org/wiki/List_of_people_in_both_the_Bible_and_the_Quran 